\title{
Seasonal and spatial variability of the OM/OC mass ratios and high regional correlation between oxalic acid and zinc in Chinese urban organic aerosols
}

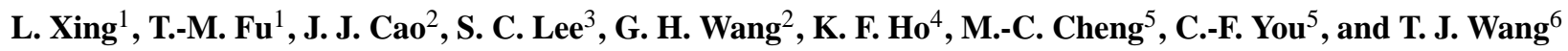 \\ ${ }^{1}$ Department of Atmospheric and Oceanic Sciences and Laboratory for Climate and Ocean-Atmosphere Studies, School of \\ Physics, Peking University, Beijing 100871, China \\ ${ }^{2}$ State Key Laboratory of Loess and Quaternary Geology, Institute of Earth Environment, Chinese Academy of Sciences, \\ Xi'an 710075, China \\ ${ }^{3}$ Research Centre of Urban Environmental Technology and Management, Department of Civil and Structural Engineering, \\ Hong Kong Polytechnic University, Hong Kong, China \\ ${ }^{4}$ School of Public Health and Primary Care, The Chinese University of Hong Kong, Hong Kong, China \\ ${ }^{5}$ Department of Earth Sciences, National Cheng Kung University, Tainan 701, Taiwan \\ ${ }^{6}$ School of Atmospheric Sciences, Nanjing University, Nanjing 210093, China \\ Correspondence to: T.-M. Fu (tmfu@pku.edu.cn)
}

Received: 13 December 2012 - Published in Atmos. Chem. Phys. Discuss.: 11 January 2013

Revised: 21 March 2013 - Accepted: 1 April 2013 - Published: 25 April 2013

\begin{abstract}
We calculated the organic matter to organic carbon mass ratios (OM/OC mass ratios) in $\mathrm{PM}_{2.5}$ collected from 14 Chinese cities during summer and winter of 2003 and analyzed the causes for their seasonal and spatial variability. The $\mathrm{OM} / \mathrm{OC}$ mass ratios were calculated two ways. Using a mass balance method, the calculated $\mathrm{OM} / \mathrm{OC}$ mass ratios averaged $1.92 \pm 0.39$ year-round, with no significant seasonal or spatial variation. The second calculation was based on chemical species analyses of the organic compounds extracted from the $\mathrm{PM}_{2.5}$ samples using dichloromethane/methanol and water. The calculated $\mathrm{OM} / \mathrm{OC}$ mass ratio in summer was relatively high $(1.75 \pm 0.13)$ and spatially-invariant due to vigorous photochemistry and secondary organic aerosol (OA) production throughout the country. The calculated OM/OC mass ratio in winter $(1.59 \pm 0.18)$ was significantly lower than that in summer, with lower values in northern cities $(1.51 \pm 0.07)$ than in southern cities $(1.65 \pm 0.15)$. This likely reflects the wider usage of coal for heating purposes in northern China in winter, in contrast to the larger contributions from biofuel and biomass burning in southern China in winter. On average, organic matter constituted $36 \%$ and $34 \%$ of Chinese urban $\mathrm{PM}_{2.5}$ mass in summer and winter, respectively. We report, for the first time, a high regional correlation between
\end{abstract}

$\mathrm{Zn}$ and oxalic acid in Chinese urban aerosols in summer. This is consistent with the formation of stable $\mathrm{Zn}$ oxalate complex in the aerosol phase previously proposed by Furukawa and Takahashi (2011). We found that many other dicarboxylic acids were also highly correlated with $\mathrm{Zn}$ in the summer Chinese urban aerosol samples, suggesting that they may also form stable organic complexes with $\mathrm{Zn}$. Such formation may have profound implications for the atmospheric abundance and hygroscopic properties of aerosol dicarboxylic acids.

\section{Introduction}

The mass ratio of organic matter $(\mathrm{OM})$ versus organic carbon (OC) in organic aerosol (OA) (hereafter referred to as $\mathrm{OM} / \mathrm{OC}$ mass ratio) is an important bulk parameter for OA chemical composition. For OA not impacted by biomass burning OA, a high OM/OC mass ratio indicates a high degree of oxidation, which suggests that a large fraction of the OA is secondary (i.e., produced in the atmosphere from gaseous organic precursors) or significantly aged (Turpin and Lim, 2001). A higher degree of oxidation in the OA often corresponds to a higher degree of hygroscopicity and lower 
surface tension (e.g., Jimenez et al., 2009; Lambe et al., 2011), which in turn affects the radiative property of the OA as well as its potential to act as cloud condensation nuclei (CCN). In addition, OM/OC mass ratios are widely used to estimate the total OM mass from OC mass in the bulk aerosol (e.g., Hand et al., 2011).

Three general methods have been used to calculate aerosol $\mathrm{OM} / \mathrm{OC}$ mass ratios. The first is the mass balance method, where OM mass is determined by the difference between the total aerosol mass and the mass sum of measured aerosol inorganic components (e.g., El-Zanan et al., 2005; Bae et al., 2006a). OC mass is usually determined by thermal/optical techniques (Chow et al., 1993). The second method is by extraction of organic species, where aerosol samples are dissolved in solvents to extract compounds in the corresponding ranges of polarity. The extraction can be weighed to determine the bulk OM mass (e.g., El-Zanan et al., 2005; Polidori et al., 2008). Alternatively, the extractions can be analyzed with chromatography and mass spectrometry techniques to resolve the molecular composition. The OM/OC mass ratios can then be calculated based on the molecular formulae and concentrations of the identified species (e.g., Turpin and Lim, 2001). A third way to calculate OM/OC mass ratio is based on functional group densities, which can be measured using aerosol mass spectrometry (AMS) or Fourier transformed infrared spectroscopy (FTIR) (e.g., Zhang et al., 2005; Aiken et al., 2008).

White and Roberts (1977) first reported an OM/OC mass ratio of 1.4 for urban $\mathrm{OA}$, based on the fraction of polar compounds extracted from aerosol samples collected in Los Angeles (Grosjean and Friedlander, 1975). Later, Turpin and Lim (2001) reviewed several organic species extraction studies and calculated OM/OC mass ratios of $1.6 \pm 0.2$ for urban OA and $2.1 \pm 0.2$ for rural OA. They pointed out that the higher $\mathrm{OM} / \mathrm{OC}$ mass ratios in rural OA indicate a larger secondary fraction and/or a higher degree of aging. Several studies also found higher aerosol OM/OC mass ratios in summer than in winter for both urban and rural OA not impacted by biomass burning, indicating stronger photochemistry and larger secondary contribution in summer (El-Zanan et al., 2005; Bae et al., 2006b; Malm et al., 2011; Simon et al., 2011). Aerosols impacted by biomass burning can have even higher OM/OC mass ratios (2.2-2.6) due to high sugar and carboxylic acid content (Turpin and Lim, 2001).

Several studies have analyzed the aerosol OM/OC mass ratios at specific urban locations in China. Chen and $\mathrm{Yu}(2007)$ calculated an annual average OM/OC mass ratio of $2.1 \pm 0.3$ for $\mathrm{PM}_{2.5}$ collected at a suburban site in Hong Kong using the mass balance method. Using the AMS, Huang et al. (2010) and $\mathrm{He}$ et al. (2011) found average $\mathrm{PM}_{1} \mathrm{OM} / \mathrm{OC}$ mass ratios of 1.58 and $1.57 \pm 0.08$ in Beijing in summer and in Shenzhen in fall, respectively. To the best of our knowledge, there has not yet been a systematic analysis of the seasonal and spatial variability of OM/OC mass ratios for Chinese urban OA.
In this study, we analyzed the OM/OC mass ratios in $\mathrm{PM}_{2.5}$ collected from 14 cities throughout China during winter and summer of 2003. We calculated the OM/OC mass ratios by two methods (mass balance and extracted organic species analyses) and estimated the uncertainties associated with each method. We examined the organic species driving the spatiotemporal variability of the OM/OC mass ratios and discussed the implications for China urban OA sources. We report, for the first time, high correlations between $\mathrm{Zn}$ and aerosol dicarboxylic acids (in particular oxalic acid) in Chinese urban OA in summer and discussed the implications for the aqueous chemistry of dicarboxylic acids.

\section{Data: chemical composition of $\mathrm{PM}_{2.5}$ in 14 Chinese cities}

$\mathrm{PM}_{2.5}$ samples were collected by Cao et al. (2007) in winter (6-20 January) and in summer (3 June to 30 July) of 2003 from 14 major cities in China, including Changchun, Beijing, Tianjin, Yulin, Jinchang, Qingdao, Xi'an, Shanghai, Wuhan, Hangzhou, Chongqing, Xiamen, Guangzhou, and Hong Kong. The geographical locations of the 14 cities are shown in Table 1 and illustrated in Fig. 1. The sampling sites were selected to represent urban-scale concentrations and were all $>100 \mathrm{~m}$ away from local sources such as major roads. Detailed descriptions of the sampling procedure and the analyses of $\mathrm{PM}_{2.5}, \mathrm{OC}$, and elemental carbon (EC) concentrations were presented in Cao et al. (2007). Briefly, each sample of $\mathrm{PM}_{2.5}$ was collected on a pre-fired quartzfiber filter by a mini-volume air sampler at a flow rate of $5 \mathrm{~L} \mathrm{~min}^{-1}$ for $24 \mathrm{~h} . \mathrm{PM}_{2.5}$ masses were determined gravimetrically against blank filters under controlled temperature and relative humidity. $\mathrm{OC}$ and $\mathrm{EC}$ concentrations were analyzed following the IMPROVE thermal/optical reflectance protocol on a DRI 2001 carbon analyzer (Chow et al., 1993). For each city, the average $\mathrm{PM}_{2.5}, \mathrm{OC}$, and EC masses were determined based on 8 to 22 samples in summer and 13 to 16 samples in winter. Figure 1 shows the mean summertime and wintertime OC concentrations for the 14 Chinese cities reported in Cao et al. (2007). OC concentrations ranged from $6.3-35 \mu \mathrm{g} \mathrm{m}^{-3}$ (average $15.8 \mu \mathrm{g} \mathrm{m}^{-3}$ ) in summer and 15$99 \mu \mathrm{g} \mathrm{m}^{-3}$ (average $36.2 \mu \mathrm{g} \mathrm{m}^{-3}$ ) in winter. Highest OC concentrations were measured in the inland industrial cities of Chongqing and Xi' an. Lowest OC concentrations were measured in the coastal cities of Qingdao, Xiamen, and Hong Kong, reflecting the ventilating effects of marine air. Measured OC concentrations in all cities except Tianjin were higher in winter than in summer, likely reflecting the stronger emissions associated with residential heating in winter.

About ten samples from each city were analyzed for inorganic compositions. $\mathrm{Na}^{+}, \mathrm{NH}_{4}^{+}, \mathrm{K}^{+}, \mathrm{SO}_{4}^{2-}, \mathrm{NO}_{3}^{-}$, and $\mathrm{Cl}^{-}$concentrations were determined by ion chromatography (Cao et al., 2012). Total concentrations of Fe, Ti, Mn, $\mathrm{Zn}, \mathrm{As}, \mathrm{Br}$, and $\mathrm{Pb}$ were determined by energy-dispersive 


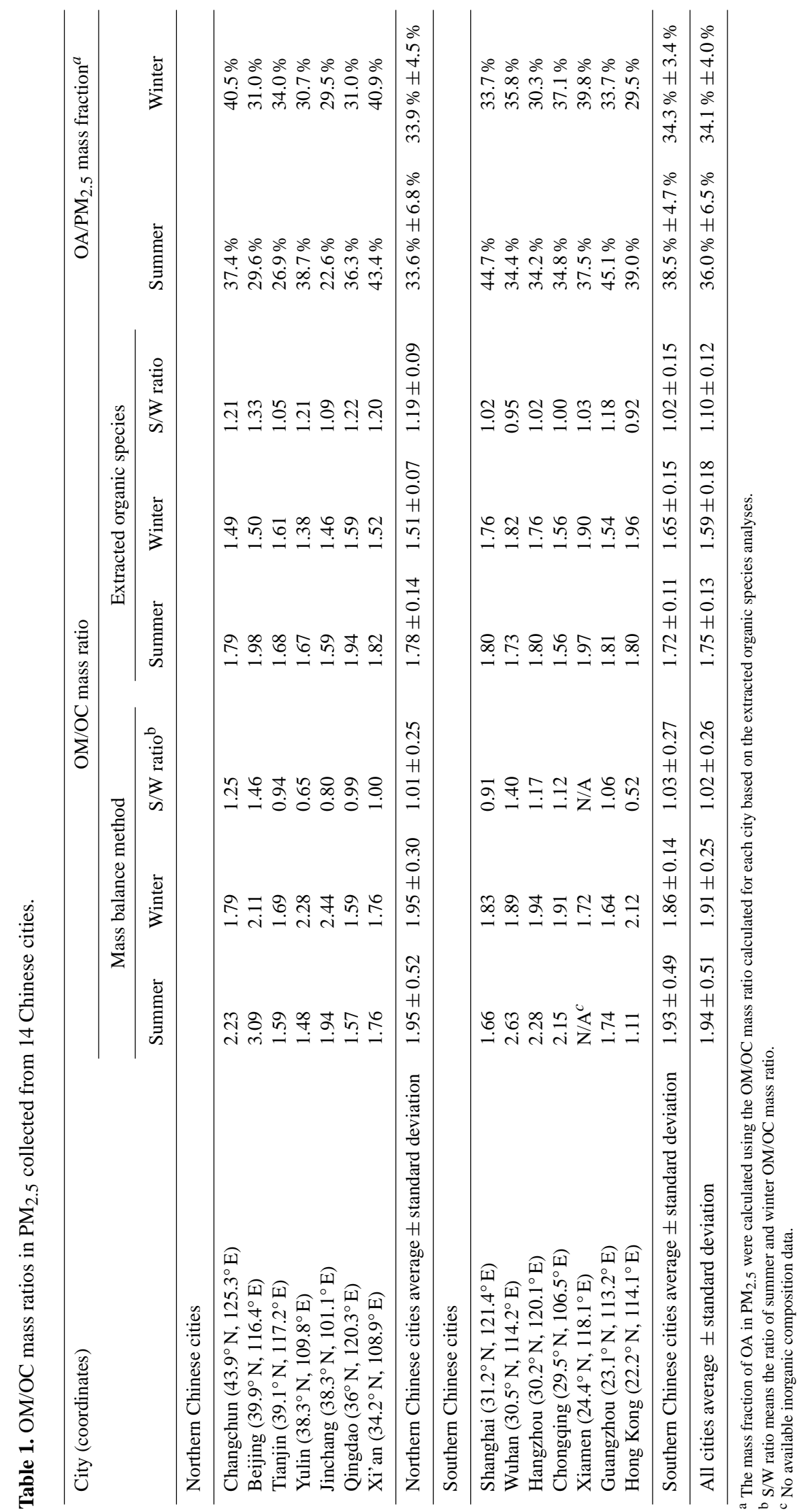




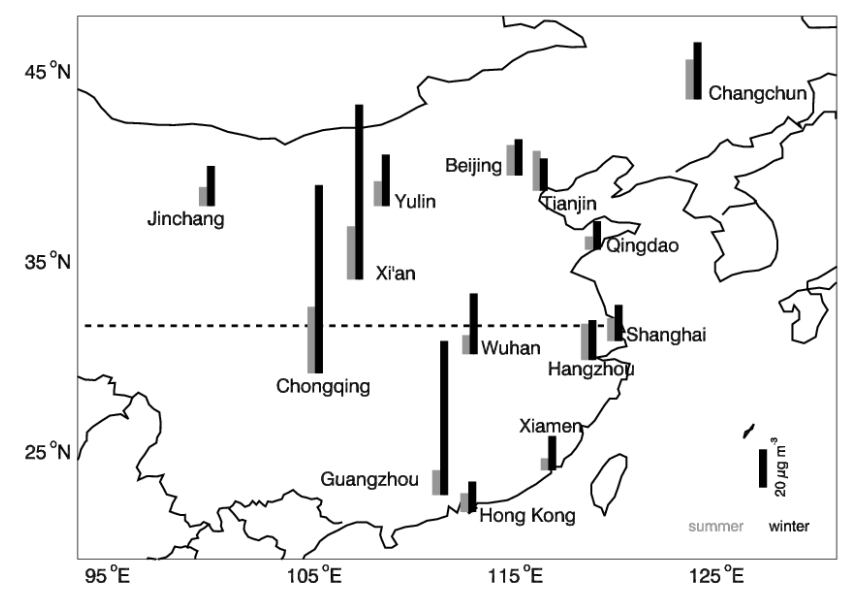

Fig. 1. OC concentrations in $\mathrm{PM}_{2.5}$ samples collected in 14 Chinese cities during summer (grey) and winter (black) of 2003. The dashed line indicates $32^{\circ} \mathrm{N}$, which divides northern and southern Chinese cities.

$\mathrm{X}$-ray fluorescence spectrometry (ED-XRF) (Cao et al., 2012). Total concentrations of $\mathrm{Ca}$ and $\mathrm{Mg}$ could not be accurately quantified by ED-XRF due to variable blank filter backgrounds and absorption biases. Instead, their watersoluble concentrations were determined by high-resolution inductively coupled plasma mass spectrometry (HR-ICPMS) (Cheng et al., 2012). Water-soluble $\mathrm{Al}, \mathrm{Cd}, \mathrm{Ni}$, and Mo concentrations were also determined by HR-ICP-MS (Cheng, unpublished data, 2012).

For each city, two summertime samples and two wintertime samples were further analyzed for organic compositions. Wang et al. (2006a) extracted filter aliquots with a mixture of dichloromethane/methanol $(2: 1, \mathrm{v} / \mathrm{v})$ under ultrasonication. The extracts were then filtered, concentrated, and treated with N,O-bis-(trimethylsilyl) trifluoroacetamide with $1 \%$ trimethylsilyl chloride and pyridine to convert the extracts to their trimethylsilyl derivatives. The derivative extracts were analyzed by gas chromatography-mass spectrometry (GC-MS) to determine the molecular compositions. Resolved species include $\mathrm{C}_{16-35}$ n-alkanes, $\mathrm{C}_{9-34}$ fatty acids, sugars, phthalates, $\mathrm{C}_{12-32}$ fatty alcohols, polyols and polyacids, lignin and resin products, sterols, polycyclic aromatic hydrocarbons (PAHs), and hopanes. The resulting concentrations measured for these species were either on the high end or exceeded the values reported for urban aerosols in other parts of the world (Wang et al., 2006b). On average, $6.5 \%$ and $6.1 \%$ of the total OC mass were chemically resolved by Wang et al. (2006a) in summer and winter, respectively.

Ho et al. (2007) extracted water-soluble organic species from the $\mathrm{PM}_{2.5}$ samples with pure water. Total water-soluble organic carbon (WSOC) in the extract was determined using the DRI Model 2001 carbon analyzer. WSOC constituted $48 \%$ and $41 \%$ of the total OC in the summertime and wintertime samples, respectively. The extracts were then filtered, concentrated, and treated with $14 \% \mathrm{BF}_{3} / \mathrm{n}$-butanol at $100^{\circ} \mathrm{C}$ to convert the carboxyl groups to butyl esters and the aldehyde groups to dibutoxy acetals. The derivatives were further extracted with n-hexane and analyzed with GC-MS. Resolved species included $\alpha, \omega$-dicarboxylic acids $\left(\mathrm{C}_{2} \sim \mathrm{C}_{12}\right)$, $\omega$-oxocarboxylic acids $\left(\mathrm{C}_{2} \sim \mathrm{C}_{9}\right)$, phthalic acid, pyruvic acid, and dicarbonyls. The resulting concentrations measured for these species in Chinese urban aerosols were generally comparable to those measured in urban aerosols in other parts of the world (Ho et al., 2007). On average, $4.6 \%$ and $2.7 \%$ of the total WSOC mass was chemically resolved by Ho et al. (2007) in summer and in winter, respectively.

\section{OM/OC mass ratios in Chinese urban $\mathbf{P M}_{2.5}$}

\subsection{Mass balance method}

We first calculated OM/OC mass ratios using the mass balance method, where the OM mass was estimated as the difference between the total $\mathrm{PM}_{2.5}$ mass and the mass sum of measured inorganic species:

$\mathrm{OM} / \mathrm{OC}=$

$\frac{\left[\mathrm{PM}_{2.5}\right]-[\mathrm{EC}]-\left[\mathrm{NH}_{4}^{+}\right]-\left[\mathrm{SO}_{4}^{2-}\right]-\left[\mathrm{NO}_{3}^{-}\right]-\left[\mathrm{Cl}^{-}\right]-[\mathrm{PBW}]-[\mathrm{TE} \text { oxides }]}{[\mathrm{OC}]-0.037[\mathrm{OC}]}$

We assumed that most trace elements were present in $\mathrm{PM}_{2.5}$ in the form of their common crustal oxide compounds (TE oxides), except $\mathrm{As}, \mathrm{Br}, \mathrm{Mo}, \mathrm{Pb}, \mathrm{Ni}$, and $\mathrm{Zn}$, which were assumed to be elemental (Bae et al., 2006a). Table 2 lists the conversion factors we used to calculate the masses of the oxide compounds from their respective trace element masses (Kleeman et al., 2000; El-Zanan et al., 2005; Bae et al., 2006a). Silicon oxides are important crustal components, but the mass of $\mathrm{Si}$ was not explicitly measured. We estimated Si mass by multiplying Al mass by 2.23 based on the mean measured Si/Al mass ratios in $\mathrm{PM}_{2.5}$ sampled in Beijing and Chongqing (Zhao et al., 2010). Particle-bound water (PBW) is the water present in the $\mathrm{PM}_{2.5}$ sample at the relative humidity under which the $\mathrm{PM}_{2.5}$ mass is weighed (35-45\%). We assumed that the PBW was $5.8 \%$ of the total $\mathrm{PM}_{2.5}$ mass following Drewnick et al. (2004). For the $24 \mathrm{~h}$-accumulated filter samples collected by Cao et al. (2007), there may be a positive artifact in OC mass due to the adsorption of organic gases on the filters, and a negative artifact due to the volatilization of semi-volatile OA from the filters. We estimated that the net artifact to be $+3.7 \%$ of the OC mass following Bae et al. (2006a).

Table 1 shows the OM/OC mass ratios calculated for the 14 Chinese cities using the mass balance method. The 14city-mean OM/OC mass ratio was $1.94 \pm 0.51$ in summer, not significantly different from that in winter $(1.91 \pm 0.25)$ (paired $t$ test, $p$ value $>0.8$ ). The ratio of summer versus winter $\mathrm{OM} / \mathrm{OC}$ averaged $1.02 \pm 0.26$. In summer, the average OM/OC mass ratios were $1.95 \pm 0.52$ for northern cities and $1.93 \pm 0.49$ for southern cities. In winter, the average 
Table 2. Mass conversion factors used in this study to calculate the mass of oxide compounds of trace elements*.

\begin{tabular}{cccc}
\hline $\begin{array}{c}\text { Trace } \\
\text { element }\end{array}$ & $\begin{array}{c}\text { Mass conversion } \\
\text { factor }\end{array}$ & $\begin{array}{c}\text { Trace } \\
\text { element }\end{array}$ & $\begin{array}{c}\text { Mass conversion } \\
\text { factor }\end{array}$ \\
\hline $\mathrm{Si}$ & 2.49 & $\mathrm{~K}$ & 1.20 \\
$\mathrm{Fe}$ & 2.42 & $\mathrm{Cd}$ & 1.14 \\
$\mathrm{Al}$ & 2.20 & $\mathrm{As}$ & 1.0 \\
$\mathrm{Mn}$ & 2.02 & $\mathrm{Mo}$ & 1.0 \\
$\mathrm{Ti}$ & 1.94 & $\mathrm{Br}$ & 1.0 \\
$\mathrm{Ca}$ & 1.63 & $\mathrm{~Pb}$ & 1.0 \\
$\mathrm{Mg}$ & 1.50 & $\mathrm{Ni}$ & 1.0 \\
$\mathrm{Na}$ & 1.50 & $\mathrm{Zn}$ & 1.0 \\
\hline
\end{tabular}

* Mass conversion factors, defined as the ratio of the molecular weight of the common oxide compound over the atomic mass of the trace element, were taken from Kleeman et al. (2000), El-Zanan et al. (2005), and Bae et al. (2006a).

OM/OC mass ratios were $1.95 \pm 0.30$ for northern cities and $1.86 \pm 0.14$ for southern cities. The spatial differences were not statistically significant in either season (two sample $t$ tests, $p$ values $>0.5$ ). The OM/OC mass ratio averaged for all cities year-round was $1.92 \pm 0.39$.

The mass balance calculation described above likely overestimated the OM mass for two reasons. Firstly, previous studies have shown that significant fractions of the aerosol nitrate mass $(50-70 \%$ in summer and $10 \%$ in winter) may evaporate from the quartz-fiber filters prior to analysis (Chow et al., 2005; Nie et al., 2010). Secondly, only the watersoluble concentrations of $\mathrm{Ca}, \mathrm{Mg}, \mathrm{Al}, \mathrm{Cd}, \mathrm{Ni}$, and Mo were measured, but these species also exist in water-insoluble form in aerosols. Schleicher et al. (2011) showed that the water-insoluble fractions of $\mathrm{Ca}, \mathrm{Mg}, \mathrm{Al}, \mathrm{Cd}$, and $\mathrm{Ni}$ accounted for $13-84 \%, 36-79 \%, 87-94 \%, 38-84 \%$, and $93-$ $98 \%$ of the total mass of these species, respectively, in $\mathrm{PM}_{2.5}$ in Beijing. Adopting the mean estimates for the fractions of evaporated nitrate and water-insoluble transient metals, we estimated that the uncertainty in the $\mathrm{OM} / \mathrm{OC}$ mass ratios calculated by the mass balance method to be $55 \%$ in summer and $12 \%$ in winter.

\subsection{Extracted organic species analyses}

We performed a second calculation of the OM/OC mass ratios by combining the extracted organic species analyses by Wang et al. (2006a) and Ho et al. (2007). A total of 129 organic species were resolved in the summertime $\mathrm{PM}_{2.5}$ samples, constituting on average $3.9 \%$ of the total $\mathrm{PM}_{2.5}$ mass and $8.9 \%$ of the total OC mass. A total of 143 organic species were resolved in the wintertime $\mathrm{PM}_{2.5}$ samples, constituting on average $2.7 \%$ of the $\mathrm{PM}_{2.5}$ mass and $7.5 \%$ of the total OC mass. The molecularly-resolved OC mass fractions were comparable to those of previous studies (Polidori et al.,
2008). The OM/OC mass ratio was calculated as

$\mathrm{OM} / \mathrm{OC}=\frac{\sum_{n=1}^{n} \mathrm{X}_{i}}{\sum_{i=1}^{n} \mathrm{X}_{i} \frac{\mathrm{M}_{\mathrm{c} i}}{\mathrm{M}_{\mathrm{m} i}}}$

where $\mathrm{X}_{i}$ is the mass concentration of organic compound $i$. $\mathrm{M}_{\mathrm{c} i}$ is molecular carbon weight in organic compound $i$, and $\mathrm{M}_{\mathrm{m} i}$ is molecular weight of organic compound $i ; n$ is the total number of identified organic compounds. For each city, we used the organic species concentrations averaged over two filter samples to calculate the OM/OC mass ratio in each season.

Table 1 shows the OM/OC mass ratios calculated based on the extracted organic species. The average OM/OC mass ratio for all 14 cities in summer was $1.75 \pm 0.13$, significantly higher than that in winter, which was $1.59 \pm 0.18$ (paired $t$ test, $p$ value $=0.005$ ). This difference was mainly driven by the seasonal changes in northern Chinese cities. In summer, the OM/OC mass ratios in northern $(1.78 \pm 0.14)$ and southern $(1.72 \pm 0.11)$ cities were not significantly different (two sample $t$ test, $p$ value $=0.4$ ). In winter, the $\mathrm{OM} / \mathrm{OC}$ mass ratios in northern cities $(1.51 \pm 0.07)$ were significantly lower than those in southern cities (1.65 \pm 0.15$)$ (two sample $t$ test, $p$ value $=0.025$ ) .

For the OM/OC mass ratios calculated here using extracted organic species analyses, both low and high biases are possible. Some potentially abundant, high-molecular-weight oxygenated organics were not resolved by either Wang et al. (2006a) or Ho et al. (2007). Examples include humic-like substances (HULIS) and oligomers in OA, both present in large amounts in Chinese urban aerosols (Lin et al., 2010; Hall and Johnston, 2012) and associated with relatively high OM/OC mass ratios (1.5-2.0) (Altieri et al., 2008; Lin et al., 2012). We estimated the associated biases in our calculated $\mathrm{OM} / \mathrm{OC}$ mass ratios to be $-3.6 \%$ in summer and $-6.5 \%$ in winter, assuming that HULIS and oxygenated oligomers each constituted $25 \%$ of the total OC mass with an average $\mathrm{OM} / \mathrm{OC}$ mass ratios of 2.0. On the other hand, Polidori et al. (2008) showed that the OM/OC mass ratios of OA extractions eluted by different solvents increase with the polarity of the solvents. The solvents used by Wang et al. (2006a) and Ho et al. (2007) (dichloromethane/methanol and water, respectively) were of low to high polarity. However, some very low polarity organic species, such as $>\mathrm{C}_{25} \mathrm{n}$-alkanes, were inefficiently extracted (Polidori et al., 2008). Studies have shown that hydrocarbon-like OA constitute $18-36 \%$ of Chinese urban OA in summer and $29.5 \%$ in winter (e.g., Huang et al., 2010; He et al., 2011; Sun et al., 2012). Assuming that $10 \%$ of the hydrocarbon-like OA was not extracted by Wang et al. (2006a) and assuming an OM/OC ratio of 1.2 for these species, our calculated OM/OC mass ratios may be slightly high-biased by $+1.3 \%$ in summer and $+0.9 \%$ in winter. The actual net bias of the OM/OC mass ratios calculated based on extracted organic species analyses are likely to be less than $-3.6 \%$ in summer and $-6.5 \%$ in winter, since the positive 
bias associated with under-extraction of low-polarity organics and the negative bias associated with under-identification of oxygenated high molecular weight organics partially offset each other.

\subsection{Organic compounds affecting $\mathrm{OM} / \mathrm{OC}$ mass ratios and implications for Chinese urban OA sources}

We wished to understand what drove the seasonal and spatial variability of the $\mathrm{OM} / \mathrm{OC}$ mass ratios in Chinese urban $\mathrm{OA}$. To this end, we re-calculated the OM/OC mass ratios based on extracted organic species, excluding one organic compound at a time. In summer, we found that the oxalic acid had the largest impact on the OM/OC mass ratios of Chinese urban OA. In winter, the top two compounds with the largest impacts on $\mathrm{OM} / \mathrm{OC}$ mass ratios were oxalic acid and levoglucosan. Oxalic acid has the highest molecule-to-carbon mass ratio (3.75) out of all the resolved organic compounds. It constituted on average $11 \%$ and $7 \%$ of the molecularly-resolved OC mass in summer and in winter, respectively. Levoglucosan also has a high molecule-to-carbon mass ratio of 2.25. It constituted on average $8.1 \%$ of the molecularly-resolved OC mass in winter.

The current understanding of the sources of oxalic acid in $\mathrm{OA}$ is that it is either emitted from biomass burning (e.g., Kundu et al., 2010) or produced secondarily from the aqueous-phase oxidation of carbonyls (e.g., Myriokefalitakis et al., 2011), which are in turn oxidation products of volatile organic compounds from anthropogenic, biogenic, and biomass burning sources. Primary anthropogenic sources of oxalic acid are thought to be small (Huang and Yu, 2007; Myriokefalitakis et al., 2011). Levoglucosan is produced by the thermal degradation of cellulose (Simoneit et al., 1999) and is often used as a molecular tracer for biomass or biofuel burning (e.g., Zhang et al., 2008).

Table 3 shows the 21 species with highest correlation against oxalic acid in Chinese urban aerosols in summer (all correlations have one-tail $p$ values $<0.025$ and are not driven by outliers. Here and throughout, all statistics were calculated from the full dataset without filtering for outliers unless otherwise noted). In summer, oxalic acid was not significantly correlated with levoglucosan $(r=0.10)$ in our Chinese urban aerosol samples. Instead, oxalic acid was most highly correlated with its known aqueous phase precursors, such as glyoxylic acid $(r=0.95)$, adipic acid $(r=0.82)$, succinic acid $(r=0.80)$, pyruvic acid $(r=0.78)$, glutaric acid $(r=0.77)$, malonic acid $(r=0.75)$, and glyoxal $(r=0.65)$ (e.g., Ervens et al., 2004; Carlton et al., 2007; Altieri et al., 2008) as well as sulfate $(r=0.66)$.

High correlations between oxalic acid (or oxalate) and sulfate in ambient aerosols have been reported in many previous studies (e.g., Yu et al., 2005; Sorooshian et al., 2006, 2007). These studies attributed such high correlations to aqueous production being the dominant source of oxalic acid, supported by time-resolved measurements and box model sim-
Table 3. The top 21 chemical species with highest correlations against oxalic acid in Chinese urban aerosols in summer ${ }^{\mathrm{a}}$

\begin{tabular}{lcc}
\hline Species & $\begin{array}{c}\text { Correlation with } \\
\text { Oxalic acid }(r)\end{array}$ & $\begin{array}{c}\text { Mean } \\
\text { concentration } \\
\left(\mathrm{ng} \mathrm{m}^{-3}\right)\end{array}$ \\
\hline Glyoxylic acid & 0.94 & 23.7 \\
2-methylglutaric acid & 0.83 & 3.66 \\
Adipic acid & 0.82 & 22.5 \\
Methylsuccinic acid & 0.81 & 9.81 \\
Pimeric acid & 0.80 & 5.96 \\
Succinic acid & 0.80 & 69.3 \\
Dodecanedioic acid & 0.80 & 0.85 \\
4-ketopimelic acid & 0.80 & 5.54 \\
Methylmalonic acid & 0.79 & 3.60 \\
Pyruvic acid & 0.78 & 2.51 \\
Glutaric acid & 0.77 & 28.4 \\
Malonic acid & 0.75 & 50.9 \\
Fumaric acid & 0.73 & 2.47 \\
Zn & 0.72 & 547 \\
Sebacic acid & 0.71 & 2.41 \\
Azelaic acid & 0.70 & 30.0 \\
Terephthalic acid & 0.69 & 32.3 \\
Phthalic acid & 0.66 & 101 \\
Sulfate & 0.66 & 12700 \\
3-Oxopropanoic acid & 0.64 & 2.19 \\
Glyoxal & 0.64 & 2.51 \\
\hline
\end{tabular}

a All correlations have one-tail $p$ values $<0.025$ and are not driven by outliers.

b Concentration averaged over the 14 Chinese cities.

ulations (e.g., Sorooshian et al., 2006). In our case, because the $\mathrm{PM}_{2.5}$ samples were collected on $24 \mathrm{~h}$ bulk filters; detailed analyses of the history of the sampled air were not possible. However, the fact that oxalic acid is highly correlated with many of its known aqueous precursors, in addition to sulfate, corroborates the idea that the oxalic acid in Chinese urban aerosols were most likely mainly produced secondarily in the aqueous phase in summer. Thus, the relatively high OM/OC mass ratio in summertime Chinese urban OA is driven by strong secondary OA production in summer. The lack of difference between the OM/OC mass ratios in northern and southern cities suggests that the precursor emissions and photochemical processes responsible for secondary OA production are strong throughout the country in the warm season.

In winter, levoglucosan and oxalic acid concentrations were both high in all 14 Chinese cities, and the two species were highly correlated $(r=0.72$, excluding Chongqing and Xi'an, where levoglucosan concentrations exceeded $2700 \mathrm{ng} \mathrm{m}^{-3}$ and were more than three times the levoglucosan concentrations of any of the other cities). This indicates that Chinese urban OA are strongly impacted by biomass and biofuel burning in winter. The difference in the $\mathrm{OM} / \mathrm{OC}$ mass ratios between northern and southern cities is mainly due to the higher contribution of biomass and biofuel 
burning in southern cities. Combined, levoglucosan and oxalic acid constituted on average $1.44 \%$ of the total wintertime OC in southern cities, while they only constituted on average $0.85 \%$ of the total wintertime OC in northern cities. In contrast, alkanes and PAH combined to make up $23.8 \%$ and $15.2 \%$ of the total wintertime OC in northern and southern cities, respectively, reflecting the larger contribution from coal burning for heating purposes in northern Chinese cities in winter (Wang et al., 2006a).

\subsection{Comparison with previous studies and contribution of $\mathrm{OA}$ to $\mathrm{PM}_{2.5}$}

Table 4 compares the OM/OC mass ratios calculated in this study against values previously reported for urban OA. Previous estimates of the $\mathrm{OM} / \mathrm{OC}$ mass ratios for urban $\mathrm{OA}$ ranged from 1.3 to 2.16 , with higher values in summer than in winter. In China, Huang et al. (2010) and He et al. (2011) found $\mathrm{OM} / \mathrm{OC}$ mass ratios of 1.58 in Beijing in summer and $1.57 \pm 0.08$ in Shenzhen in fall, respectively. The range and seasonal variability of our calculated $\mathrm{OM} / \mathrm{OC}$ mass ratios are consistent with these previous studies. Chen and Yu (2007) reported a high OM/OC mass ratio of $2.1 \pm 0.3$ for Hong Kong with little seasonal variation, likely reflecting the stronger photochemistry and secondary production in southern China year-round.

We calculated the seasonal contributions of OA to urban $\mathrm{PM}_{2.5}$, using the $\mathrm{OM} / \mathrm{OC}$ mass ratios calculated from the extracted organic species analyses for each city in summer and in winter. OA constituted $23-45 \%$ (average $36 \%$ ) of the urban $\mathrm{PM}_{2.5}$ mass in summer and 29-41\% (average $34 \%$ ) of the urban $\mathrm{PM}_{2.5}$ mass in winter. The contributions of OA to $\mathrm{PM}_{2.5}$ mass did not vary significantly with season for each city, nor were they significantly different between northern and southern Chinese cities in either season.

\section{High correlation between aerosol oxalic acid and zinc and its implications}

During our analysis, we unexpectedly found that oxalic acid was highly correlated with $\mathrm{Zn}$ in the Chinese urban aerosol samples in summer (all cities $r=0.72$; northern cities $r=0.74$; southern cities $r=0.89$ ). Figure 2 shows the scatter plot of the molar concentrations of oxalic acid and $\mathrm{Zn}$ in the Chinese urban aerosol samples in summer. Table 3 shows the 21 species with highest correlation against oxalic acid in Chinese urban aerosols in summer. All of the species with higher correlation against oxalic acid than zinc were either known aqueous precursors of oxalic acid or other dicarboxylic acids, which may have aqueous production pathways similar to those of oxalic acid (e.g., Ervens et al., 2004; Carlton et al., 2007; Altieri et al., 2008). To the best of our knowledge, such high correlation between aerosol oxalic acid and

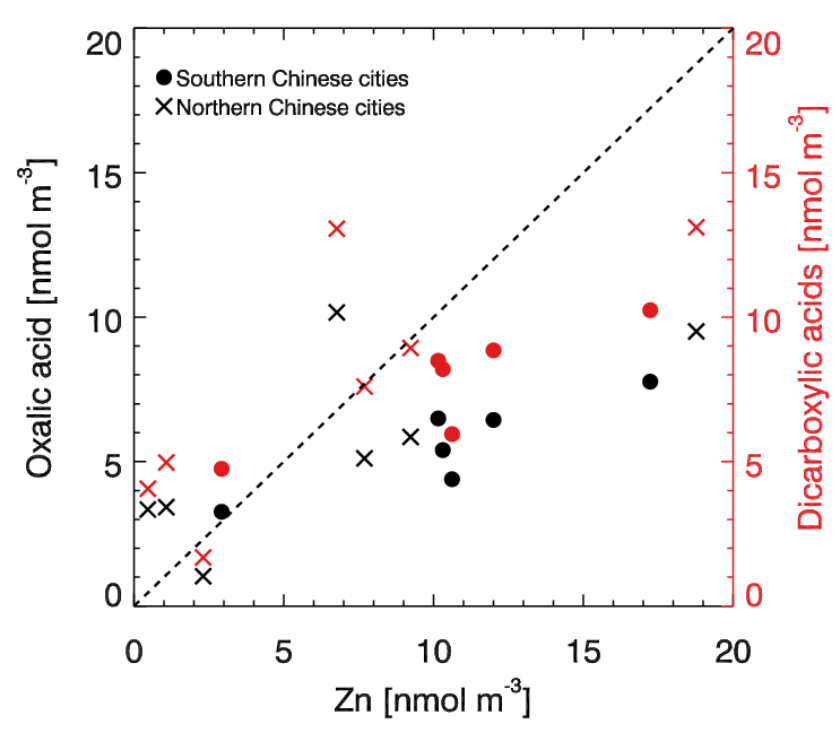

Fig. 2. Zn versus oxalic acid molar concentrations (black) in aerosol samples collected from 14 Chinese cities in summer 2003. Also shown in red are the molar concentrations of $\mathrm{Zn}$ versus the the sum of the molar concentrations of the 12 dicarboxylic acids (terephthalic acid, 4-ketopimelic acid, oxalic acid, dodecanedioic acid, malonic acid, malic acid, phthalic acid, azelaic acid, glutaric acid, fumaric acid, adipic acid, and sebacic acid) that were highly correlated with $\mathrm{Zn}$ in the summertime Chinese urban aerosol samples. The dashed line indicates $1: 1$ molar concentrations.

$\mathrm{Zn}$ on a regional scale has never been reported. We discuss the implications here.

There are five possible explanations for the high correlation between oxalic acid and $\mathrm{Zn}$ in Chinese urban aerosols in summer. The first is that the correlation merely reflects the contrast in $\mathrm{PM}_{2.5}$ pollution severity among the different cities. We found this not to be the case, as oxalic acid and $\mathrm{Zn}$ were still significantly correlated when normalized by $\mathrm{PM}_{2.5}$ mass $(r=0.54)$. A second possibility is that oxalic acid and $\mathrm{Zn}$ are of the same primary sources. Known sources of aerosol $\mathrm{Zn}$ are mainly anthropogenic, with largest emissions from $\mathrm{Zn}$ mining and production, followed by vehicle tire abrasion, waste incineration, iron/steel and copper mining and production, fertilizer production, and cement production (Councell et al., 2004). Measurements in Mexico City and in Beijing showed that $\mathrm{Zn}$ particles were mainly from industrial activities and waste incineration (Moffet et al., 2008; Li and Shao, 2009). There is also some $\mathrm{Zn}$ emission from biomass burning (Gaudichet et al., 1995). However, we found no significant correlations between oxalic acid and other chemical tracers indicative of primary anthropogenic or biomass burning emissions, such as $\mathrm{Pb}$ and levoglucosan. In addition, Huang and $\mathrm{Yu}$ (2007) showed that there is no significant vehicular emission of oxalic acid. Myriokefalitakis et al. (2011) modeled the global oxalic acid budget and showed that the primary sources are far too low to account for the atmospheric abundance of oxalic acid. 
Table 4. Comparisons of OM/OC mass ratios for urban aerosols in the literature ${ }^{\mathrm{a}}$.

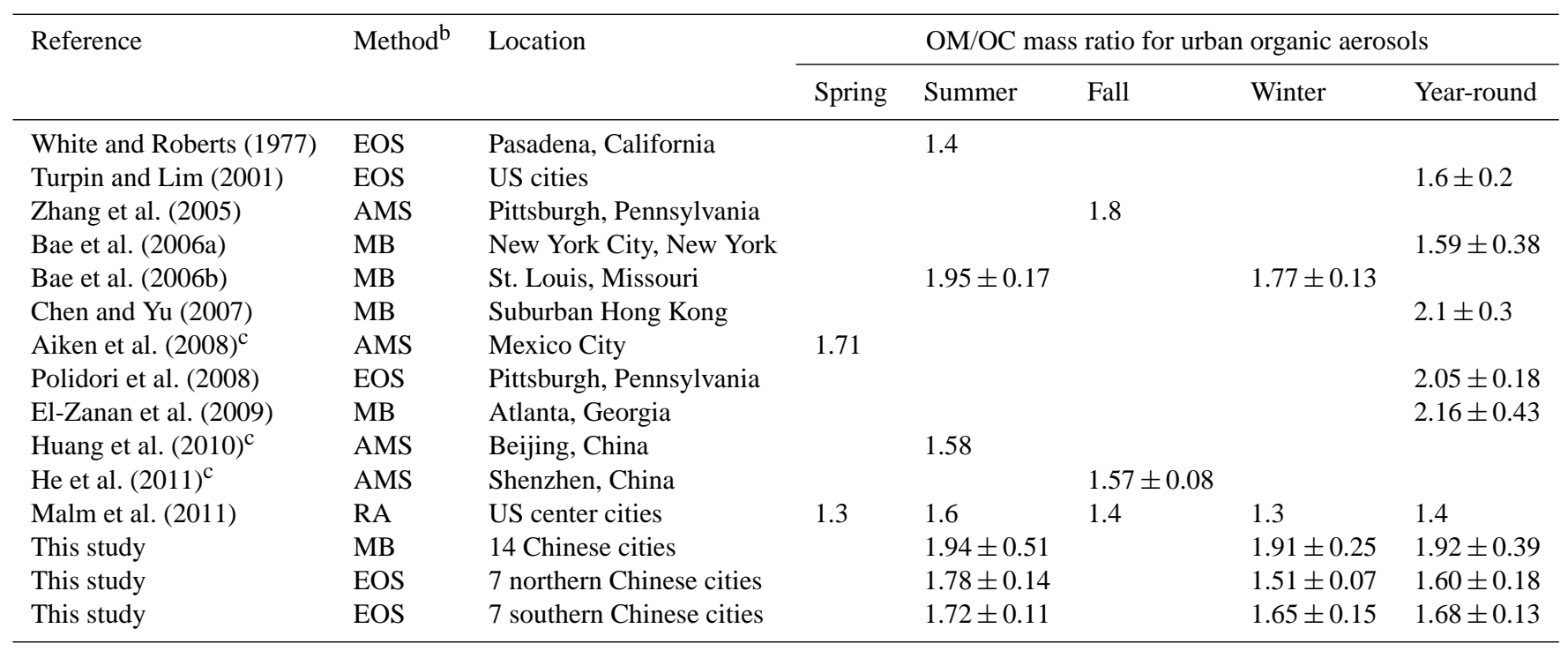

a The sampled aerosols were $\mathrm{PM}_{2.5}$ unless otherwise noted.

b EOS: extracted organic species; MB: mass balance; AMS: aerosol mass spectrometry; RA: regression analysis.

c The sampled aerosol was $\mathrm{PM}_{1}$.

A third possibility is that the anthropogenic sources that emit $\mathrm{Zn}$ also emit the precursors of oxalic acid, but we found that this was not the main driver for the high correlation between $\mathrm{Zn}$ and oxalic acid. Sorooshian et al. (2006) analyzed aircraft measurement of urban pollution plumes and found that aerosol oxalic acid was correlated with toluene emitted from anthropogenic sources. However, we found no correlation between $\mathrm{Zn}$ and glyoxal or methylglyoxal, the two intermediate oxidation products of toluene leading to oxalic acid formation. Table 5 shows the top 22 chemical species with the highest correlations against $\mathrm{Zn}$ in Chinese urban aerosols in summer. Aside from the dicarboxylic acids, glyoxlic acid, and pyruvic acid, $\mathrm{Zn}$ was highly correlated with di-iso-butyl and di-n-butyl phthalate, $\mathrm{OC}, \mathrm{Mo}, \mathrm{K}^{+}, \mathrm{Mn}$, and $\mathrm{C}_{16}$ fatty acid, reflecting the anthropogenic origin of $\mathrm{Zn}$. However, with the exception of OC, none of these latter species had a high correlation with oxalic acid.

Our analyses above led to the fourth possibility, which is that the stability or secondary formation of aerosol oxalic acid is somehow enhanced at high $\mathrm{Zn}$ concentrations. In this study, oxalic acid was measured by GC after derivation to butyl ester, but it may be present in the aerosol as its anion, oxalate. Kawamura et al. (2010) showed that the aerosol oxalic acid concentrations measured by GC after derivatization agree well (4\% difference) with the oxalate concentrations measured by ion chromatography (IC) without derivatization. Furukawa and Takahashi (2011) hypothesized that oxalate may react with metal ions in the aerosol to form metal oxalate complexes that precipitate, decreasing the hygroscopicity of oxalate. These metal oxalate complexes dissolve when aerosol samples are diluted with water during the
Table 5. The top 22 species with highest correlations against $\mathrm{Zn}$ in Chinese urban aerosols in summer ${ }^{\mathrm{a}}$.

\begin{tabular}{lll}
\hline Species & $\begin{array}{l}\text { Correlation with } \\
\mathrm{Zn}(r)\end{array}$ & $\begin{array}{l}\text { Mean } \\
\text { concentration } \\
\left(\mathrm{ng} \mathrm{m}^{-3}\right)\end{array}$ \\
\hline Terephthalic acid & 0.78 & 32.8 \\
4-ketopimelic acid & 0.76 & 5.53 \\
Oxalic acid & 0.72 & 500 \\
Dodecanedioic acid & 0.72 & 0.89 \\
Diisobutyl phthalate & 0.71 & 128 \\
n-alkanes $\left(\mathrm{C}_{21}\right)$ & 0.71 & 17.6 \\
OC & 0.70 & 13600 \\
Glyoxylic acid & 0.69 & 24.5 \\
Mo & 0.69 & 96.2 \\
Malonic acid & 0.66 & 52.3 \\
$\mathrm{~K}^{+}$ & 0.66 & 1380 \\
Fatty acid $\left(\mathrm{C}_{17}\right)$ & 0.65 & 6.49 \\
Pyruvic acid & 0.65 & 2.58 \\
Mn & 0.61 & 47.7 \\
Phthalic acid & 0.61 & 105 \\
Fatty acid $\left(\mathrm{C}_{16}\right)$ & 0.60 & 176 \\
n-alkanes $\left(\mathrm{C}_{30}\right)$ & 0.60 & 4.05 \\
Di-n-butyl phthalate & 0.59 & 147 \\
Azelaic acid & 0.58 & 31.2 \\
Fumaric acid & 0.57 & 2.53 \\
Glutaric acid & 0.57 & 29.6 \\
Adipic acid & 0.57 & 22.7 \\
\hline
\end{tabular}

a All correlations have one-tail $p$ value $<0.025$ and are not driven by outliers.

$\mathrm{b}$ Concentration averaged over the 14 Chinese cities. 
pre-processing for either GC or IC analysis, and thus have not been detected previously. Furukawa and Takahashi (2011) used X-ray absorption fine structure spectroscopy to characterize the $\mathrm{Zn}$ and $\mathrm{Ca}$ in size-segregated urban aerosol samples collected in Japan in winter and in summer. They showed that $20-100 \%$ and $10-60 \%$ of the total $\mathrm{Zn}$ and $\mathrm{Ca}$ in the fine particles were present as $\mathrm{Zn}$ and $\mathrm{Ca}$ oxalate complexes, respectively. Some $60-80 \%$ of the total oxalate in $0.65-2.1 \mu \mathrm{m}$ $\mathrm{PM}$ was present as either $\mathrm{Zn}$ or Ca oxalates, with $\mathrm{Zn}$ oxalate being more abundant. Moreover, they found that the ratio of $\mathrm{Zn}$ oxalate to total $\mathrm{Zn}$ increased with decreasing particle size, suggesting that $\mathrm{Zn}$ oxalate may be formed at the particle surface.

Our report of high correlation between aerosol oxalic acid and $\mathrm{Zn}$ across 14 Chinese cities in summer is consistent with the formation of $\mathrm{Zn}$ oxalate complex. Moreover, it suggests that such formation may be the determining factor to secondary oxalic acid abundance on a regional scale, either by enhancing oxalate formation at the particle surface, or by preventing oxalic acid to further oxidize to eventually form $\mathrm{CO}_{2}$. This has profound implications not only for the global and regional abundance of aerosol oxalic acid, but also its hygroscopicity and CCN activity (Sullivan et al., 2009), which in turn determines their direct and indirect radiative forcing.

Furukawa and Takahashi (2011) further hypothesized that other dicarboxylic acids and heavy metals may also form similar stable organic metal complexes, and our analysis is in support of this. Table 5 shows the top 22 chemical species with highest correlations against $\mathrm{Zn}$ in Chinese urban aerosols in summer. In addition to oxalic acid, many other high-concentration dicarboxylic acids, such as phthalic acid, malonic acid, glutaric acid, and azelaic acid, are also highly correlated with $\mathrm{Zn}$ (all correlations not driven by outliers and all one-tail $p$ values $<0.025$ ). We added up the molar concentrations of the 12 dicarboxylic acid species with high correlations against $\mathrm{Zn}$ shown in Table 5. The molar ratios of $\mathrm{Zn}$ relative to the sum of these dicarboxylic acids for the 14 cities ranged from 0.11 to 1.78 , with an average of 1.05. This is consistent with the picture that large fractions of both dicarboxylic acid and $\mathrm{Zn}$ exist in the aerosol as organic Zn complexes. Glyoxylic acid and pyruvic acid, two important aqueous-phase precursors to oxalic acid, were also highly correlated with $\mathrm{Zn}$. This may imply that $\mathrm{Zn}$ participates in the aqueous chemistry of carboxylic acids even before the formation of oxalic acid, although the exact mechanism is currently unknown.

In winter, oxalic acid was not significantly correlated with $\mathrm{Zn}$ in the Chinese urban aerosol samples (Figure S1 in the supplementary material). This may be because the oxalic acid emitted by biomass burning was present in coarser particles than that produced by secondary production (Wang et al., 2012). Alternatively, it may be because there is an overabundance of $\mathrm{Zn}$ in Chinese urban aerosols in winter, such that the oxalic acid concentrations were not limited by $\mathrm{Zn}$ concentrations. We added up the wintertime molar concen- trations of the dicarboxylic acids that were strongly correlated with $\mathrm{Zn}$ in summer. The molar ratios of $\mathrm{Zn}$ relative to the sum of these dicarboxylic acids for each city ranged from 0.22 to 6.06, with an average of 1.88. Moffet et al. (2008) used single particle mass spectrometry to characterize ambient aerosols in northern Mexico City in March 2006. They showed that $\mathrm{Zn}$ was mainly from industrial activities and waste incineration, while oxalate was mainly associated with biomass burning and urban sources. They found no significant correlation between aerosol oxalate and zinc.

We found no significant correlation between oxalic acid and $\mathrm{Ca}$ in the Chinese urban aerosols in summer or in winter, perhaps because oxalic acid exists in finer particles than $\mathrm{Ca}$ does. Alternatively, it may be because only water-soluble $\mathrm{Ca}$ was measured by Cheng et al. (2012), such that Ca oxalate complexes were filtered out.

A final possible explanation for the high correlation between $\mathrm{Zn}$ and aerosol oxalic acid is that the formation of stable $\mathrm{Zn}$ oxalate complex took place on the bulk $\mathrm{PM}_{2.5}$ filters. Any additional oxalic acid not forming $\mathrm{Zn}$ oxalate complex may have evaporated prior to analysis. If this be the case, then all aerosol oxalic acid measurements based on bulk PM filter samples in areas heavily impacted by anthropogenic sources $(\mathrm{Zn})$ and/or dust (Ca) may be significantly low-biased. Clearly, more detailed, time- and size-resolving measurements are needed to examine the roles of $\mathrm{Zn}$ and $\mathrm{Ca}$ in the aqueous chemistry of oxalic acid and other dicarboxylic acids.

\section{Conclusions}

We analyzed the $\mathrm{OM} / \mathrm{OC}$ mass ratios in $\mathrm{PM}_{2.5}$ collected from 14 cities throughout China during winter and summer of 2003 and analyzed the causes for their seasonal and spatial variability. The $\mathrm{PM}_{2.5}$ samples were collected on quartz filters analyzed to determine total mass, EC and OC mass, as well as inorganic compositions. Concentrations of organic species were determined by extraction using dichloromethane/methanol and water, followed by analysis with GC-MS.

We used two methods to calculate the OM/OC mass ratios. Using the mass balance method, the calculated OM/OC mass ratios averaged $1.92 \pm 0.39$ year-round, with no significant seasonal or spatial variation. We estimated that the uncertainty in the $\mathrm{OM} / \mathrm{OC}$ mass ratios calculated by the mass balance method to be $+55 \%$ in summer and $+12 \%$ in winter, due to partial evaporation of nitrate prior to analyses and underestimation of transient metal concentrations.

We conducted a second calculation based on the extracted organic species analyses and examined the causes for the seasonal and spatial variability of the $\mathrm{OM} / \mathrm{OC}$ mass ratios. The calculated OM/OC mass ratio in summer was relatively high $(1.75 \pm 0.13)$ and spatially-invariant due to vigorous photochemistry and secondary OA production throughout 
the country. The calculated $\mathrm{OM} / \mathrm{OC}$ mass ratio in winter $(1.59 \pm 0.18)$ was significantly lower than that in summer, with lower values in northern cities $(1.51 \pm 0.07)$ than in southern cities $(1.65 \pm 0.15)$. This likely reflects the wider usage of coal for heating purposes in northern China in winter, in contrast to the larger contributions from biofuel and biomass burning in southern China in winter. We estimated that the net bias of the OM/OC mass ratios calculated based on extracted organic species analyses to be less than $-3.6 \%$ in summer and $-6.5 \%$ in winter, since the positive bias associated with under-extraction of low-polarity organics and the negative bias associated with under-identification of oxygenated high molecular weight organics partially offset each other. On average, organic matters constituted $36 \%$ and $34 \%$ of Chinese urban $\mathrm{PM}_{2.5}$ mass in summer and in winter, respectively.

We report, for the first time, high regional correlations between $\mathrm{Zn}$ and oxalic acid in Chinese urban aerosols in summer. This is consistent with the formation of stable $\mathrm{Zn}$ oxalate complex in the aerosol phase previously proposed by Furukawa and Takahashi (2011). We found that many other dicarboxylic acids were also highly correlated with $\mathrm{Zn}$ in the summer Chinese urban aerosol samples, suggesting that they may also form stable organic complexes with $\mathrm{Zn}$. Such formation may have profound implications for the atmospheric abundance and hygroscopic property of aerosol dicarboxylic acids. More detailed, time- and size-resolving measurements are needed to examine the interactions between metals and carboxylic acids in aerosols and the impacts on the abundance and hygroscopicity of OA.

\section{Supplementary material related to this article is available online at: http://www.atmos-chem-phys.net/13/ 4307/2013/acp-13-4307-2013-supplement.pdf.}

Acknowledgements. This work was supported by the National Natural Science Foundation of China (41222035), the Ministry of Education of China (20110001110090), the Chinese Academy of Sciences (XDA05100401), and the Research Grants Council of Hong Kong (PolyU5175/09E).

Edited by: K. Schaefer

\section{References}

Aiken, A. C., DeCarlo, P. F., Kroll, J. H., Worsnop, D. R., Huffman, J. A., Docherty, K. S., Ulbrich, I. M., Mohr, C., Kimmel, J. R., Sueper, D., Sun, Y., Zhang, Q., Trimborn, A., Northway, M., Ziemann, P. J., Canagaratna, M. R., Onasch, T. B., Alfarra, M. R., Prevot, A. S. H., Dommen, J., Duplissy, J., Metzger, A., Baltensperger, U., and Jimenez, J. L.: O/C and OM/OC ratios of primary, secondary, and ambient organic aerosols with highresolution time-of-flight aerosol mass spectrometry, Environ. Sci. Technol., 42, 4478-4485, doi:10.1021/es703009q, 2008.
Altieri, K. E., Seitzinger, S. P., Carlton, A. G., Turpin, B. J., Klein, G. C., and Marshall, A. G.: Oligomers formed through in-cloud methylglyoxal reactions: Chemical composition, properties, and mechanisms investigated by ultra-high resolution FT-ICR mass spectrometry, Atmos. Environ., 42, 1476-1490, doi:10.1016/j.atmosenv.2007.11.015, 2008.

Bae, M. S., Demerjian, K. L., and Schwab, J. J.: Seasonal estimation of organic mass to organic carbon in $\mathrm{PM}_{2.5}$ at rural and urban locations in New York state, Atmos. Environ., 40, 7467-7479, doi:10.1016/j.atmosenv.2006.07.008, 2006a.

Bae, M. S., Schauer, J. J., and Turner, J. R.: Estimation of the monthly average ratios of organic mass to organic carbon for fine particulate matter at an urban site, Aerosol Sci. Technol., 40, 1123-1139, doi:10.1080/02786820601004085, 2006b.

Cao, J. J., Lee, S. C., Chow, J. C., Watson, J. G., Ho, K. F., Zhang, R. J., Jin, Z. D., Shen, Z. X., Chen, G. C., Kang, Y. M., Zou, S. C., Zhang, L. Z., Qi, S. H., Dai, M. H., Cheng, Y., and Hu, K.: Spatial and seasonal distributions of carbonaceous aerosols over China, J. Geophys. Res., 112, D22S11, doi:10.1029/2006JD008205, 2007.

Cao, J. J., Shen, Z. X., Chow, J. C., Watson, J. G., Lee, S. C., Tie, X. X., Ho, K. F., Wang, G. H., and Han, Y. M.: Winter and summer $\mathrm{PM}_{2.5}$ chemical compositions in fourteen Chinese Cities, J. Air Waste Manage. Assoc., 62, 1214-1226, doi:10.1080/10962247.2012.701193, 2012.

Carlton, A. G., Turnpin, B. J., Altieri, K. E., Seitzinger, S., Reff, A., Lim, H.-J., and Ervens, B.: Atmospheric oxalic acid and SOA production from glyoxal: results of aqueous photooxidation experiments, Atmos. Environ., 41, 7588-7602, doi:10.1016/j.atmosenv.2007.05.035, 2007.

Chen, X. and Yu, J. Z.: Measurement of organic mass to organic carbon ratio in ambient aerosol samples using a gravimetric technique in combination with chemical analysis, Atmos. Environ., 41, 8857-8864, doi:10.1016/j.atmosenv.2007.08.023, 2007.

Cheng, M. C., You, C. F., Cao, J. J., and Jin, Z. D.: Spatial and seasonal variability of water-soluble ions in $\mathrm{PM}_{2.5}$ aerosols in 14 major cities in China, Atmos. Environ., 60, 182-192, doi:10.1016/j.atmosenv.2012.06.037, 2012.

Chow, J. C., Watson, J. G., Pritchett, L. C., Pierson, W. R., Frazier, C. A., and Purcell, P. G.: The DRI thermal/optical reflectance carbon analysis system: Description, evaluation and applications in US air quality studies, Atmos. Environ., Part A, 27, 11851201, doi:10.1016/0960-1686(93)90245-T, 1993.

Chow, J. C., Watson, J. G., Lowenthal, D. H., and Magliano, K. L.: Loss of $\mathrm{PM}_{2.5}$ nitrate from filter samples in central California, $\mathrm{J}$. Air Waste Manage. Assoc., 55, 1158-1168, 2005.

Councell, T., Duckenfield, K., Landa, E., and Callender, E., Tire wear particles as a source of zinc to the environment, Environ. Sci. Technol., 38, 4206-4214, doi:10.1021/es034631f, 2004.

Drewnick, F., Schwab, J. J., Jayne, J. T., Canagaratna, M., Worsnop, D. R., and Demerjian, K. L.: Measurement of ambient aerosol composition during the PMTACS-NY 2001 using an aerosol mass spectrometer. Part I: Mass concentrations, Aerosol Sci. Technol., 38, 92-103, doi:10.1080/02786820390229507, 2004.

El-Zanan, H. S., Lowenthal, D. H., Zielinska, B., Chow, J. C., and Kumar, N.: Determination of the organic aerosol mass to organic carbon ratio in IMPROVE samples, Chemosphere, 60, 485-496, doi:10.1016/j.chemosphere.2005.01.005, 2005. 
El-Zanan, H. S., Zielinska, B., Mazzoleni, L. R., and Hansen, D. A.: Analytical determination of the aerosol organic mass-toorganic carbon ratio, J. Air Waste Manage. Assoc., 59, 58-69, doi:10.3155/1047-3289.59.1.58, 2009.

Ervens, B., Feingold, G., Frost, G. L., and Kreidenweis, S. M.: A modeling study of aqueous production of dicarboxylic acids: 1 . Chemical pathways and speciated organic mass production, J. Geophys. Res., 109, doi:10.1029/2003JD004387, 2004.

Furukawa, T. and Takahashi, Y.: Oxalate metal complexes in aerosol particles: implications for the hygroscopicity of oxalatecontaining particles, Atmos. Chem. Phys., 11, 4289-4301, doi:10.5194/acp-11-4289-2011, 2011.

Gaudichet, A., Echalar, F., Charenet, B., Quisefit, J. P., and Malingre, G.: Trace elements in tropical African savanna biomass burning aerosols, J. Atmos. Chem., 22, 19-39, doi:10.1007/BF00708179, 1995.

Grosjean, D. and Friedlander, S. K.: Gas-particle distribution factors for organic and other pollutants in Los-Angeles atmopsphere, J. Air Pollut. Contr. Assoc., 25, 1038-1044, 1975.

Hall, W. A. and Johnston, M. V.: Oligomer formation pathways in secondary organic aerosol from MS and MS/MS measurements with high mass accuracy and resolving power, J. Am. Soc. Mass Spectrom., 23, 1097-1108, doi:10.1007/s13361-012-03626, 2012.

Hand, J. L., Copeland, S. A., Day, D. E., Dillner, A. M., Indresand, H., Malm, W. C., McDade, C. E., Moore Jr., C. T., Pitchford, M. L., Schichtel, B. A., and Watson, J. G.: IMPROVE (Interagency Monitoring of Protected Visual Environments): Spatial and seasonal patterns and temporal variability of haze and its constituents in the United States, Report V, CIRA Report ISSN:0737-5352-87, Colorado State Univ., Fort Collins, CO, USA, 2011.

He, L. Y., Huang, X. F., Xue, L., Hu, M., Lin, Y., Zheng, J., Zhang, R., and Zhang, Y. H.: Submicron aerosol analysis and organic source apportionment in an urban atmosphere in Pearl River Delta of China using high-resolution aerosol massspectrometry, J. Geophys. Res., 116, D12304, doi:10.1029/2010JD014566, 2011.

Ho, K. F., Cao, J. J., Lee, S. C., Kawamura, K., Zhang, R. J., Chow, J. C., and Watson, J. G.: Dicarboxylic acids, ketocarboxylic acids, and dicarbonyls in the urban atmosphere of China, J. Geophys. Res., 112, D22S27, doi:10.1029/2006JD008011, 2007.

Huang, X. F. and Yu, J. Z.: Is vehicle exhaust a significant primary source of oxalic acid inambient aerosols?, Geophys. Res. Lett., 34, L02808, doi:10.1029/2006GL028457, 2007.

Huang, X. F., He, L. Y., Canagaratna, M. R., Sun, Y., Zhang, Q., Zhu, T., Xue, L., Zeng, L. W., Liu, X. G., Zhang, Y. H., Jayne, J. T., Ng, N. L., and Worsnop, D. R.: Highly time-resolved chemical characterization of atmospheric submicron particles during 2008 Beijing Olympic Games using an Aerodyne high-resolution aerosol mass spectrometer, Atmos. Chem. Phys., 10, 8933-8945, doi:10.5194/acp-10-8933-2010, 2010.

Jimenez, J. L., Canagaratna, M. R., Donahue, N. M., Prevot, A. S. H., Zhang, Q., Kroll, J. H., DeCarlo, P. F., Allan, J. D., Coe, H., Ng, N. L., Aiken, A. C., Docherty, K. S., Ulbrich, I.M., Grieshop, A. P., Robinson, A. L., Duplissy, J., Smith, J. D., Wilson, K. R., Lanz, V. A., Hueglin, C., Sun, Y. L., Tian, J., Laaksonen, A., Raatikainen, T., Rautiainen, J., Vaattovaara, P., Ehn, M., Kulmala, M., Tomlinson, J. M., Collins, D. R., Cubison, M. J., Dun- lea, E. J., Huffman, J. A., Onasch, T. B., Alfarra, M. R., Williams, P. I., Bower, K., Kondo, Y., Schneider, J., Drewnick, F., Borrmann, S., Weimer, S., Demerjian, K., Salcedo, D., Cottrell,L., Griffin, R., Takami, A., Miyoshi, T., Hatakeyama, S.,Shimono, A., Sun, J. Y., Zhang, Y. M., Dzepina, K., Kimmel, J. R.,Sueper, D., Jayne, J. T., Herndon, S. C., Trimborn, A. M., Williams, L. R., Wood, E. C., Middlebrook, A. M., Kolb, C. E., Baltensperger, U., and Worsnop, D. R.: Evolution of organic aerosols in the atmosphere, Science, 326, 1525-1529, doi:10.1126/science.1180353, 2009.

Kawamura, K., Barrie, L. A., and Toom-Sauntry, D.: Intercomparison of the measurements of oxalic acid in aerosols by gas chromotography and ion chromatography, Atmos. Environ., 44, 5316-5319, doi:10.1016/j.atmosenv.2010.08.051, 2010.

Kleeman, M. J., Schauer, J. J., and Cass, G. R.: Size and composition distribution of fine particulate matter emitted from motor vehicles, Environ. Sci. Technol., 34, 1132-1142, doi:10.1021/es981276y, 2000.

Kundu, S., Kawamura, K., Andreae, T. W., Hoffer, A., and Andreae, M. O.: Molecular distributions of dicarboxylic acids, ketocarboxylic acids and alpha-dicarbonyls in biomass burning aerosols: implications for photochemical production and degradation in smoke layers, Atmos. Chem. Phys., 10, 2209-2225, doi:10.5194/acp-10-2209-2010, 2010.

Lambe. A. T., Onasch, T. B., Massoli, P., Croasdale, D. R., Wright, J. P., Ahern, A. T., Williams, L. R., Worsnop, D. R., Brune, W. H., and Davidovits, P.: Laboratory studies of the chemical composition and cloud condensation nuclei $(\mathrm{CCN})$ activity of secondary organic aerosol(SOA) and oxidized primary organic aerosol (OPOA), Atmos. Chem. Phys., 11, 8913-8928, doi:10.5194/acp-11-8913-2011, 2011.

Li, W. and Shao, L: Transmission electron microscopy study of aerosol particles from the brown hazes in northern China, J. Geophys. Res., 114, D09302, doi:10.1029/2008JD011285, 2009.

Lin, P., Engling, G., and Yu, J. Z.: Humic-like substances in fresh emissions of rice straw burning and in ambient aerosols in the Pearl River Delta Region, China, Atmos. Chem. Phys., 10, 64876500, doi:10.5194/acp-10-6487-2010, 2010.

Lin, P., Rincon, A. G., Kalberer, M. K., and Yu, J. Z.: Elemental composition of HULIS in the Pearl River Delta Region, China: results inferred from positive and negative electrospray high resolution mass spectrometric data, Environ. Sci. Technol., 46, 7454-7462, doi:10.1021/es300285d, 2012.

Malm, W. C., Schichtel, B. A., and Pitchford, M. L.: Uncertainties in $\mathrm{PM}_{2.5}$ gravimetric and speciation measurements and what we can learn from them, J. Air Waste Manage. Assoc., 61, 11311149, doi:10.1080/10473289.2011.603998, 2011.

Moffet, R. C., de Foy, B., Molina, L. T., Molina, M. J., and Prather, K. A.: Measurement of ambient aerosols in northern Mexico City by single particle mass spectrometry, Atmos. Chem. Phys., 8 , 4499-4516, doi:10.5194/acp-8-4499-2008, 2008.

Myriokefalitakis, S., Tsigaridis, K., Mihalopoulos, N., Sciare, J., Nenes, A., Kawamura, K., Segers, A., and Kanakidou, M.: In-cloud oxalate formation in the global troposphere: a 3-D modeling study, Atmos. Chem. Phys., 11, 5761-5782, doi:10.5194/acp-11-5761-2011, 2011.

Nie, W., Wang, T., Gao, X. M., Pathak, R. K., Wang, X. F., Gao, R., Zhang, Q. Z., Yang, L. X., and Wang, W. X.: Comparison among filter-based, impactor-based and continuous techniques for mea- 
suring atmospheric fine sulfate and nitrate, Atmos. Environ., 44, 4396-4403, doi:10.1016/j.atmosenv.2010.07.047, 2010.

Polidori, A., Turpin, B. J., Davidson, C. I., Rodenburg, L. A., and Maimone, F.: Organic $\mathrm{PM}_{2.5}$ : Fractionation by polarity, FTIR spectroscopy, and $\mathrm{OM} / \mathrm{OC}$ ratio for the Pittsburgh aerosol, Aerosol Sci. Technol., 42, 233-246, doi:10.1080/02786820801958767, 2008.

Schleicher, N. J., Norra, S., Chai, F. H., Chen, Y. Z., Wang, S. L., Cen, K. Q., Yu, Y., and Stuben, D.: Temporal variability of trace metal mobility of urban particulate matter from Beijing - A contribution to health impact assessments of aerosols, Atmos. Environ., 45, 7248-7265, doi:10.1016/j.atmosenv.2011.08.067, 2011.

Simon, H., Bhave, P. V., Swall, J. L., Frank, N. H., and Malm, W. C.: Determining the spatial and seasonal variability in OM/OC ratios across the US using multiple regression, Atmos. Chem. Phys., 11, 2933-2949, doi:10.5194/acp-11-2933-2011, 2011.

Simoneit, B. R. T., Schauer, J. J., Nolte, C. G., Oros, D. R., Elias, V. O., Fraser, M. P., Rogge, W. F., and Cass, G. R.: Levoglucosan, a tracer for cellulose in biomass burning and atmospheric particles, Atmos. Environ., 33, 173-182, doi:10.1016/S13522310(98)00145-9, 1999.

Sorooshian, A., Varutbangkul, V., Brechtel, F. J., Ervens, B., Feingold, G., Bahreini, R., Murphy, S. M., Holloway, J. S., Atlas, E. L., Buzorius, G., Jonsson, H., Flagan, R. C., and Seinfeld, J. H.: Oxalic acid in clear and cloudy atmospheres: analysis of data from International Consortium for Atmospheric Research on Transport and Transformation 2004, J. Geophys. Res., 111, D23S45, doi:10.1029/2005JD006880, 2006.

Sorooshian, A., Ng, N. L., Chan, A. W. H., Feingold, G., Flagan, R. C., and Seinfeld, J. H.: Particulate organic acids and overall water-soluble aerosol composition measurements from the 2006 Gulf of Mexico Atmospheric Composition and Climate Study (GoMACCS), J. Geophys. Res., 112, D13201, doi:10.1029/2007JD008537, 2007.

Sullivan, R. C., Moore, M. J. K., Petters, M. D., Kreidenweis, S. M., Roberts, G. C., and Prather, K. A.: Effect of chemical mixing state on the hygroscopicity and cloud nucleation properties of calcium mineral dust particles, Atmos. Chem. Phys., 9, 33033316, doi:10.5194/acp-9-3303-2009, 2009.

Sun, Y., Wang, Z., Dong, H., Yang, T., Li, J., Pan, X., Chen, P., and Jayne, J. T.: Characterization of summer organic and inorganic aerosols in Beijing, China with an Aerosol Chemical Speciation Monitor, Atmos. Environ., 51, 250-259, doi:10.1016/j.atmosenv.2012.01.013, 2012.
Turpin, B. J. and Lim, H. J.: Species contributions to $\mathrm{PM}_{2.5}$ mass concentrations: Revisiting common assumptions for estimating organic mass, Aerosol Sci. Technol., 35, 602-610, doi:10.1080/02786820152051454, 2001.

Wang, G. H., Kawamura, K., Lee, S. C., Ho, K. F., and Cao, J. J.: Molecular, seasonal and spatial distribution of organic aerosols from fourteen Chinese cities, Environ. Sci. Technol., 40, 46194625, doi:10.1021/es060291x, 2006a.

Wang, G. H., Kawamura, K., Watanabe, T., Lee, S. C., Ho, K. F., and Cao, J. J.: High loadings and source strengths of organic aerosols in China, Geophys. Res. Lett., 33, L22801, doi:10.1029/2006GL027624, 2006b.

Wang, G. H., Kawamura, K., Cheng, C. L., Li, J. J., Cao, J. J., Zhang, R. J., Zhang, T., Liu, S. X., and Zhao, Z. Z.: Molecular distribution and stable carbon isotopic composition of dicarboxylic acids, ketocarboxylic acids, and alpha-dicarbonyls in size-resolved atmospheric particles from Xi'an City, China, Environ. Sci. Technol., 46, 4783-4791, doi:10.1021/es204322c, 2012.

White, W. H. and Roberts, P. T.: Nature and origins of visibilityreducing aerosols in Los-Angeles air basin, Atmos. Environ., 11, 803-812, doi:10.1016/0004-6981(77)90042-7, 1977.

Yu, J. Z., Huang, X. F., Xu, J. H., and Hu, M.: When aerosol sulfate goes up, so does oxalate: Implication for the formation mechanisms of oxalate, Environ. Sci. Technol., 39, 128-133, doi:10.1021/es049559f, 2005.

Zhang, Q., Worsnop, D. R., Canagaratna, M. R., and Jimenez, J. L.: Hydrocarbon-like and oxygenated organic aerosols in Pittsburgh: insights into sources and processes of organic aerosols, Atmos. Chem. Phys., 5, 3289-3311, doi:10.5194/acp-5-32892005, 2005.

Zhang, T., Claeys, M., Cachier, H., Dong, S. P., Wang, W., Maenhaut, W., and Liu, X. D.: Identification and estimation of the biomass burning contribution to Beijing aerosol using levoglucosan as a molecular marker, Atmos. Environ., 42, 7013-7021, doi:10.1016/j.atmosenv.2008.04.050, 2008.

Zhao, Q., He, K. B., Rahn, K. A., Ma, Y. L., Yang, F. M., and Duan, F. K.: Using Si depletion in aerosol to identify the sources of crustal dust in two Chinese megacities, Atmos. Environ., 44, 2615-2624, doi:10.1016/j.atmosenv.2010.04.015, 2010. 